\title{
Gastric peroral endoscopic myotomy for gastroparesis, after botulinum toxin injection
}

A 45-year-old woman had refractory Epstein-Barr virus-associated gastroparesis. Despite lifestyle modification and medication therapy, the patient had recurrent hospitalizations for gastroparesis. Management also included four previous sessions of endoscopic botulinum toxin injection. Despite transient symptomatic improvement, the patient's symptoms had recurred. She was not a candidate for surgical implantation of a gastric pacemaker, so she was referred for gastric peroral endoscopic myotomy (G-POEM).

During the procedure ( $\triangleright$ Video 1 ), a submucosal bleb was created with a methylene blue and saline solution, $6 \mathrm{~cm}$ proximal to the gastroesophageal junction. A mucosal entry point was incised with a multipurpose knife and an endoscope was advanced into the submucosa. The submucosal space was dissected using intermittent injection and dissection with spray coagulation current.

In patients who have not undergone previous botulinum toxin injection, injection of the submucosa will facilitate separation between the mucosa and muscle layers ( Fig. 1) However, this patient's submucosal tunnel demonstrated significant scarring. The botulinum toxin caused areas of fusion of the mucosa and the muscularis with dense scarring and opaque submucosa leading to a more challenging dissection ( $\triangleright$ Video 1 ).

Once the submucosal tunnel was dissected down to the pylorus level, pyloromyotomy was performed. The submucosal tunnel was washed with topical liquid gentamicin, and the mucosal entry site was closed using multiple endoscopic sutures.

At 3 months' follow-up, the patient has regained a normal quality of life with weight gain of $10 \mathrm{~kg}$.

G-POEM is a novel endoscopic therapy for refractory gastroparesis, that involves mucosal entry, submucosal tunneling, pyloromyotomy, and closure of the mu-

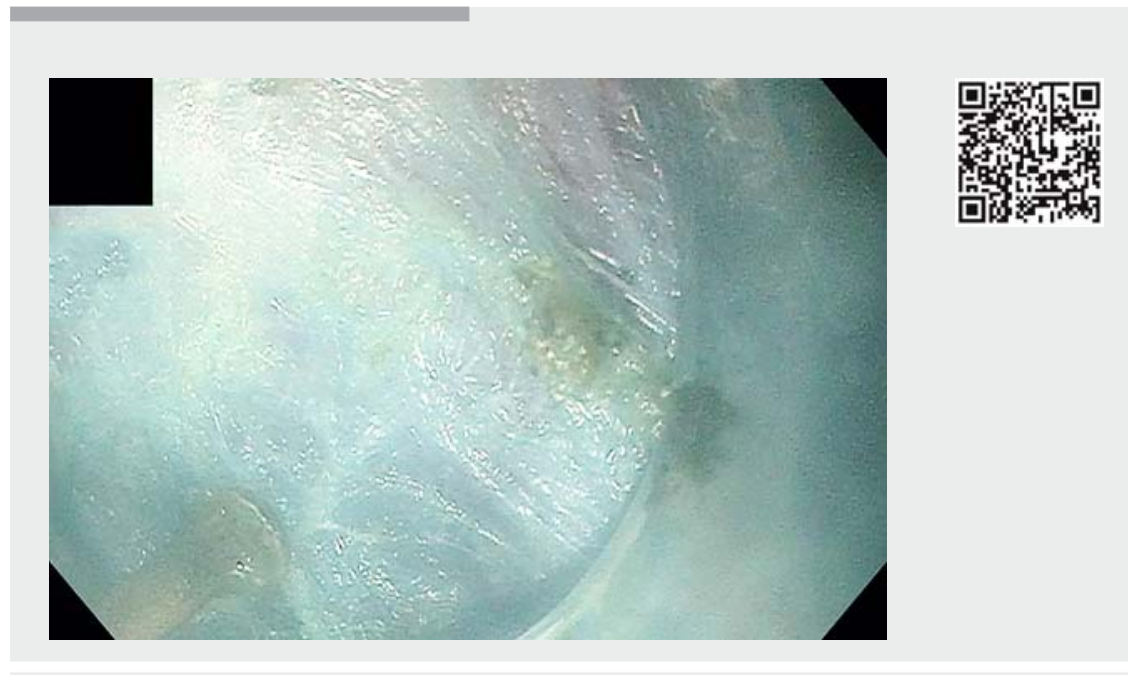

Video 1 Gastric peroral endoscopic myotomy (G-POEM) for refractory gastroparesis in a patient who had previously received botulinum toxin injections; submucosal tunnelling is compared to dissection in a patient without botulinum toxin injection.
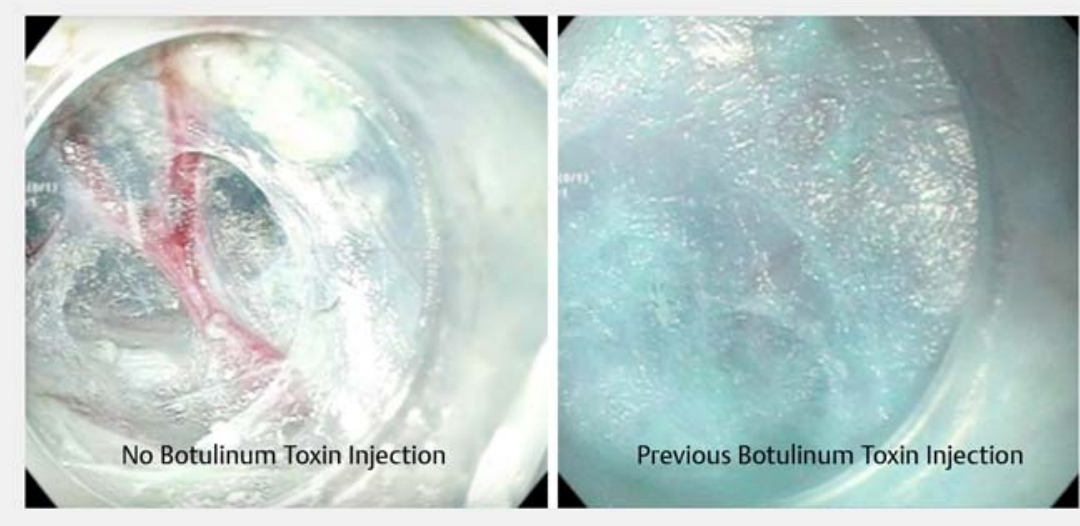

- Fig. 1 Submucosal tunnel dissection for gastric peroral endoscopic myotomy (G-POEM). Right: In the present patient, who had previously received botulinum toxin injections. The botulinum toxin caused areas of fusion of the mucosa and muscularis, forming a dense and opaque submucosa. Left: Submucosal tunnel in a patient who had not had botulinum toxin.

cosal entry site. It is associated with an $86 \%$ symptomatic improvement in patients with refractory gastroparesis [1]. Previous endoscopic botulinum toxin injection is associated with a more challenging submucosal tunneling ( $>$ Fig.1). Recent studies recommend against endoscopic botulinum toxin injection for gastroparesis [2-4]. > Video 1 highlights the submucosal fibrosis secondary to botulinum toxin injection that leads to a more challenging dissection during G-POEM.

Endoscopy_UCTN_Code_TTT_1AO_2AN 
Michel Kahaleh MD: has received grant support from Boston Scientific, Fujinon, EMcison, Xlumena Inc., W.L. Gore, MaunaKea, Apollo Endosurgery, Cook Endoscopy, ASPIRE Bariatrics, GI Dynamics, NinePoint Medical, Merit Medical, Olympus and MI Tech. He is a consultant for Boston Scientific, Xlumena Inc., Concordia Laboratories Inc, ABBvie, and MaunaKea Tech.

All other authors have no conflicts of interest to report.

\section{The Authors}

Monica Saumoy ${ }^{1}$, Najib Nassani ${ }^{1}$, Joaquin Ortiz $^{2}$, Viviana Parra ${ }^{3}$, Amy Tyberg ${ }^{1}$, Michel Kahaleh ${ }^{1}$

1 Division of Gastroenterology and Hepatology New York Presbyterian Hospital, Weill Cornell Medical College, New York, United States

2 Instituto Nacional de Cancerologia, Delegacion Tlalpan, Mexico City, Mexico

3 Clinica Universitaria Columbia, Bogota, Colombia

\section{Michel Kahaleh, MD}

1305 York Ave, 4th Floor, New York, NY 10021, United States

Fax: 01-646-962-0110

mkahaleh@gmail.com

\section{References}

[1] Khashab MA, Ngamruengphong S, CarrLocke D et al. Gastric per-oral endoscopic myotomy for refractory gastroparesis: results from the first multicenter study on endoscopic pyloromyotomy (with video). Gastrointest Endosc 2017; 85: 123 - 128

[2] Arts ], Holvoet L, Caenepeel P et al. Clinical trial: a randomized-controlled crossover study of intrapyloric injection of botulinum toxin in gastroparesis. Aliment Pharmacol Ther 2007; 26: 1251 - 1258

[3] Friedenberg FK, Palit A, Parkman HP et al. Botulinum toxin A for the treatment of delayed gastric emptying. Am J Gastroenterol 2008; 103: 416-423

[4] Camilleri M, Parkman HP, Shafi MA et al. Clinical guideline: management of gastroparesis. Am J Gastroenterol 2013; 108: 18 37

\section{Bibliography}

DOI https://doi.org/10.1055/s-0043-115888

Published online: 31.7.2017

Endoscopy 2017; 49: E256-E257

(c) Georg Thieme Verlag KG

Stuttgart · New York

ISSN 0013-726X

\section{ENDOSCOPY E-VIDEOS}

https:/|eref.thieme.de/e-videos

回回 Endoscopy E-Videos is a free access online section, reporting 回制 on interesting cases and new

techniques in gastroenterological endoscopy. All papers include a high quality video and all contributions are freely accessible online.

This section has its own submission website at https://mc.manuscriptcentral.com/e-videos 